\title{
ORAL COMPLICATIONS OF HIV DISEASE
}

\author{
Jair C. Leao, ${ }^{\mathrm{I}}$ Camila M. B. Ribeiro, ${ }^{\mathrm{I}}$ Alessandra A. T. Carvalho, ${ }^{\mathrm{I}}$ Cristina \\ Frezzini, ${ }^{I I}$ Stephen Porter ${ }^{\mathrm{II}}$
}

doi: 10.1590/S1807-59322009000500014

Leão JC, Ribeiro CMB, Carvalho AAT, Frezzini C, Porter S. Oral complications of HIV disease. Clinics. 2009;64(5):45970.

Oral lesions are among the early signs of HIV infection and can predict its progression to acquired immunodeficiency syndrome (AIDS). A better understanding of the oral manifestations of AIDS in both adults and children has implications for all health care professionals. The knowledge of such alterations would allow for early recognition of HIV-infected patients. The present paper reviews epidemiology, relevant aspects of HIV infection related to the mouth in both adults and children, as well as current trends in antiretroviral therapy and its connection with orofacial manifestations related to AIDS.

KEYWORDS: HIV; AIDS; Oral diseases; Oral manifestations; Mouth.

\section{EPIDEMIOLOGY OF HIV INFECTION AND ITS CURRENT TRENDS}

HIV infection remains a significant health care problem. ${ }^{1}$ Since Barre-Sonoussi and Gallo's initial description of the human immunodeficiency virus type I (HIV-1) in 1983 and Clavel et al. first described HIV-2 in 1986, these two viruses have been recognized for almost 20 years as the primary cause of the acquired immunodeficiency syndrome (AIDS). ${ }^{2}$

By the end of 2005, an estimated 40.3 million people were alive with HIV infection in the world, the vast majority of whom were resident in low-income countries. ${ }^{3}$ However, in 2007, advances in the methodology of estimating HIV epidemics applied to an expanded range of country data, resulting in substantial changes to the estimates of the number of persons living with HIV worldwide; nevertheless, the qualitative interpretation of the severity and implications of the pandemic have altered little. ${ }^{4}$ The estimated number of persons living with HIV worldwide in 2007 is now assumed to be 33.2 million [30.6-36.1 million], a reduction of $16 \%$

\footnotetext{
I Departamento de Clinica e Odontologia Preventiva, Universidade Federal de Pernambuco - Recife/PE, Brazil.

II Oral Medicine, Division of Maxillofacial Diagnostic, Medical and Surgical Sciences, UCL Eastman Dental Institute - London, UK.

Email: jleao@ufpe.br

Tel.: 55812126.8818

Received for publicaiton on January 22, 2009

Accepted for publication on February 18, 2009
}

compared with the estimate published in 2006 (39.5 million [34.7-47.1 million]). ${ }^{4}$ Of this number, only 1.6 million live in high-income countries; the remaining more than 95\% of HIV-infected people live in developing countries. ${ }^{5}$ In developed countries, the number of children newly infected with HIV has decreased dramatically. However, in developing countries, there are an estimated 3.5 million children younger than the age of 15 who are infected. In developing countries in 2007, an estimated 330,000 children younger than the 15 years of age died of AIDS, and more children younger than the age of 5 years die from AIDS now than from any other cause. ${ }^{6}$

The prevalence and incidence of HIV/AIDS vary considerably from continent to continent, from country to country, and from region to region. Several countries in sub-Saharan Africa report infection rates of 30\%, especially in urban areas; however, in other countries, HIV prevalence still remains low. Low national prevalence rates can be misleading. They often disguise serious epidemics that are initially concentrated in certain localities or among specific population groups and that threaten to spill over into the wider population. ${ }^{7}$

HIV infection leading to AIDS has been a major cause of illness and death among children, teens, and young adults worldwide. AIDS has been the sixth leading cause of death in the United States among 15- to 24-year-olds since 1991. In recent years, AIDS infection rates have been increasing 
rapidly among teens and young adults. Half of all new HIV infections in the United States occur in people under 25; thousands of teens acquire new HIV infections each year. ${ }^{8}$ In 2007 alone, 420,000 infants and children were newly infected with HIV in developing countries, more than 1,150 every day. An estimated 330,000 children died from HIV and AIDS during 2007, joining more than 4 million children already claimed by the epidemic. ${ }^{6}$

There are several ways in which someone can become infected with HIV, and some of these transmission routes are well defined. HIV infection can be transmitted through unprotected sexual intercourse with an infected partner The HIV virus can be transmitted through unprotected oral sex, both from fellatio and cunnilingus, although the precise degree of risk of disease transmission to and from the mouth is difficult to establish as these practices often take place along with insertive sexual intercourse. ${ }^{9}$ Injection or transfusion of contaminated blood or blood products (infection through artificial insemination, skin grafts, and organ transplants is also possible),${ }^{10}$ sharing unsterilized injection equipment that was previously used by an infected person, ${ }^{11}$ and maternalfetal transmission (during pregnancy, at birth, and through breastfeeding) $)^{12,13}$ are other transmission routes.

Occupational HIV infections of healthcare or laboratory workers may occur, but this mode of infection is not frequent. ${ }^{14}$ Transmission of HIV from an infected patient to a health-care worker has been documented after parenteral or mucous-membrane exposure to blood. However, this risk is less than $1 \%$, is limited to exposure to blood, and can be further minimized through the availability of more effective antiretroviral therapy (ART). ${ }^{15}$

There remains little evidence that HIV is transmitted via oral fluids. ${ }^{16}$ However, saliva seems to play an important role in an individual's protection from HIV infections. The saliva of non-HIV-infected persons contains non-immune endogenous inhibitors of HIV such as mucins, defensins, thrombospondin, and various salivary proteins, in particular the secretory leukocyte protease inhibitor. ${ }^{17}$ There is also evidence that the hypotonicity of saliva itself exerts a significant inhibitory effect on cell-associated HIV replication. ${ }^{18}$

The risk of transmission of HIV from a patient to a dental health care worker remains very low, if not infinitesimal. ${ }^{19}$ Transmission of HIV from an infected dental health care worker is also rare, although possible. ${ }^{20}$ Nevertheless, dental health care workers are at risk of nosocomial acquisition of HIV and other blood-borne viruses (BBVs), and these individuals should be aware of, and follow available national guidelines on occupational exposure to BBVs. ${ }^{21}$

As in other virus infections, the individual course of HIV infection depends on both host and viral factors; however, the factors that may predispose one to or promote the development of the AIDS syndrome are largely unknown..$^{23}$ The clinical course of AIDS described in the following sentences refers to HIV infection in the absence of highly active antiretroviral therapy (HAART). Several factors, including immunological and virological variables, have been reported to predict disease progression. ${ }^{24}$ The acute viral syndrome of primary HIV infection (which is defined as the time period from initial infection with HIV to the development of an antibody response) shows symptoms that often resemble those of mononucleosis. ${ }^{25}$ These symptoms appear within days to weeks of exposure to HIV. However, clinical signs and symptoms may not occur in all patients. ${ }^{26}$

After the acute infection, equilibrium between viral replication and the host immune response is usually reached, and many infected individuals may have no clinical manifestations of HIV infection for years. Even in the absence of antiretroviral treatment, this period of clinical latency may last 8-10 years or more. ${ }^{27}$ However, the term "latency period" may be misleading, given the incredibly high turnover of the virus and the relentless daily destruction of CD4+ T-cells..$^{28}$ At the end of the latency period, a number of symptoms or illnesses may appear that do not fulfill the definition of AIDS. These symptoms include slight immunological, dermatological, hematological, neurological, and orofacial signs. ${ }^{29}$

Oral manifestations are among the earliest and most important indicators of HIV infection. ${ }^{30}$ At present, three groups of oral manifestations of AIDS are defined based on their intensity and features. Group 1 is composed of seven cardinal lesions (oral candidosis, hairy leukoplakia, Kaposi sarcoma, linear gingival erythema, necrotizing ulcerative gingivitis, necrotizing ulcerative periodontitis, and non-Hodgkin lymphoma) that are strongly associated with HIV infection. ${ }^{31}$ The second group includes atypical ulcers, salivary glands diseases, viral infection such as cytomegalovírus (CMV), herpes simplex virus (HSV), papillomavirus (HPV), and herpes zoster virus (HZV). On group 3 are lesion rarer than those on groups 1 and 2, such as diffuse osteomyelitis and squamous cell carcinoma. ${ }^{32}$ The presence of oral lesions can have a significant impact on health-related quality of life. Oral health is strongly associated with physical and mental health, and there are significant increases in oral health needs in people with HIV infection, especially in children, and in adults particularly in relation to periodontal diseases. Thus, physical and mental health measures of HIV patients should incorporate indicators of oral functioning and well-being. Data obtained in the Coutler et al. study have shown that a one-point increase in oral health was associated with a $0.05(\mathrm{p}<0.000)$ increase in mental health and a 0.02 increase in physical health $(\mathrm{p}=0.031){ }^{33}$ 


\section{ADVANCEMENT IN THE TREATMENT OF HIV DISEASE}

Significant advancement has been made in the treatment of HIV disease. This progress has contributed to a decrease in AIDS-related deaths and, consequently, has increased the number of individuals living with HIV throughout the world. ${ }^{34}$ The treatment of HIV is directed principally towards the specific inhibition of HIV replication (antiretroviral therapy) and the prevention and management of opportunistic infections and malignancies, ${ }^{35}$ therefore, the ultimate goal of antiretroviral therapy should always be borne in mind: to prolong the patient's life while maintaining the best possible quality of health and life. ${ }^{36}$

Antiretroviral drugs (ARDs) now comprise four classes of agents: nucleoside analog reverse transcriptase inhibitors (NRTIs), non-nucleoside analog reverse transcriptase inhibitors (NNRTIs), protease inhibitors (PIs), and entry inhibitors. ${ }^{37}$ This last class of drug blocks HIV entry into host cells and has only become clinically available recently; these drugs include attachment inhibitors, coreceptor inhibitors, and fusion inhibitors, and they are usually reserved for treating HIV-1 infection in treatmentexperienced patients. ${ }^{38}$

Combination therapy, using three or more drugs (usually, but not always, two NRTIs and either a PI or NNRTI) reduces HIV viremia to below detectable levels. ${ }^{39}$ Such combination therapy, known better as antiretroviral therapy (ART) or highly active antiretroviral therapy (HAART), has greatly improved the prognosis for persons infected with HIV. However, as with almost all antimicrobials, in vivo resistance to NRTIs, NNRTIs, and PIs has been documented as well as transmission of antiretroviral resistant strains of HIV..$^{40}$ In addition, the various ARDs can give rise to a wide spectrum of orofacial adverse reactions, such as erythema multiforme, hyperpigmentation, ulcers, cheilitis, lipodystrophy syndrome, and so on; the relationships of these reactions to the drugs used are summarized in Table 1. HIV-associated lipodystrophy syndrome is considered to be one of the most clinically relevant adverse effects of ART. ${ }^{41}$ This syndrome is characterized by a generalized loss of fatty tissue. ${ }^{42}$ The nasolabial regions and temples are the most common sites of facial involvement, although orbital fat can also be lost when fatty tissue loss is severe. Fat wasting in the limbs leads to prominence of the subcutaneous veins while that of the face and buttocks leads to marked hollowing and wrinkling of the skin. ${ }^{43}$ Effective ARTs are rarely available to HIV-infected persons in the developing world, particularly in areas of Africa. In some countries that have no specific HIV therapy, the treatment of HIV disease is still principally directed toward the elimination of opportunistic infections,
Table 1 - Oral and systemic side effects of antiretroviral drugs (ARDs)

\begin{tabular}{|c|c|c|}
\hline Oral side effect & Class of drug & Name of drug \\
\hline \multirow[t]{2}{*}{ Erythema multiforme } & NRTIs & $\begin{array}{l}\text { Zidovudine (ZVD) } \\
\text { Abacavir }(A B C) \\
\text { Didanosine }(D D I) \\
\text { Zalcitabine } \\
\end{array}$ \\
\hline & NNRTIs & $\begin{array}{l}\text { Efavirenz } \\
\text { Delaviridine } \\
\text { Nevirapine } \\
\text { Saquinavir } \\
\end{array}$ \\
\hline Hyperpigmentation & NRTIs & Zidovudine (ZVD) \\
\hline \multirow[t]{2}{*}{ Lipodystrophy } & NRTIs & Stavudine \\
\hline & PIs & $\begin{array}{l}\text { Saquinavir } \\
\text { Ritonavir } \\
\end{array}$ \\
\hline \multirow[t]{2}{*}{ Xerostomia } & NRTIs & $\begin{array}{l}\text { Lamivudine (3TC) } \\
\text { Didanosine }\end{array}$ \\
\hline & PIs & $\begin{array}{l}\text { Saquinavir } \\
\text { Indinavir } \\
\text { Nelfinavir } \\
\text { Ritonavir } \\
\end{array}$ \\
\hline Parotid lipomatosis & PIs & $\begin{array}{l}\text { Indinavir } \\
\text { Ritonavir } \\
\text { Saquinavir } \\
\text { Nelfinavir } \\
\text { Amprenavir }\end{array}$ \\
\hline Cheilitis & PI & Indinavir \\
\hline Perioral paresthesia & PIs & $\begin{array}{l}\text { Ritonavir } \\
\text { Amprenavir }\end{array}$ \\
\hline Taste disturbances & PIs & $\begin{array}{l}\text { Indinabir } \\
\text { Ritonavir } \\
\end{array}$ \\
\hline Facial edema & PIs & Ritonavir \\
\hline Ulcers & NRTIs & $\begin{array}{l}\text { Abacavir } \\
\text { Zalcitabine } \\
\text { Nevirapine }\end{array}$ \\
\hline Lip enlargement & EIs & Enfuvirtide \\
\hline
\end{tabular}

NRTI = nucleoside analog reverse transcriptase inhibitors; NNRTI = nonnucleoside analog reverse transcriptase inhibitors; PIs = protease inhibitors; $\mathbf{E I}=$ entry inhibitors

and even this treatment is often unavailable. ${ }^{44}$ In the absence of specific HIV therapy, health care resources are being increasingly utilized but with little survival benefit for the individual. Resources available for treating patients vary considerably between the richer and poorer countries of the continent. ${ }^{45}$ For example fluconazole only recently became widely available in South Africa, and even topical antiseptic agents, such as gentian violet which are used in Uganda to treat trigeminal zoster infections, are of limited availability. Extracts of traditionally used East African medicinal plants (e.g., Entada abyssinica, Terminalia spinosa, Harrisonia abyssinica, Ximenia caffra, Azadirachta indica, and Zahna Africana) that have in vitro antifungal actions have been advocated as possible therapeutic alternatives to more expensive antifungal agents. ${ }^{46}$ Likewise, $0.5 \%$ lawsone methyl ether preparations with in vitro antifungal activity similar to that of chlorhexidine gluconate and $1.0 \%$ 
clotrimazole cream have been suggested for the treatment of candidal infections in the developing world. ${ }^{47}$

Antiretroviral therapy is very effective at suppressing viral replication. However, viral rebound with resistance does occur, primarily due to sub-optimal compliance and drug toxicities. It is during the period of failing HAART when the HIV load may well be high or rising that the transmission of drug-resistant HIV to susceptible individuals occurs. ${ }^{48}$ The aforementioned trends in anti-HIV therapy are of relevance to general dental practice. People living with HIV infection may complain of, or have, orofacial features of ART. In contrast, HIV-infected individuals taking ART are likely to have the well-recognized, common orofacial features of untreated HIV disease or may develop others oral manifestations related to ART. $^{49}$

\section{CURRENT ASPECTS OF THE ORAL MANIFESTA- TIONS OF AIDS}

Since the advent of HAART, clinical and epidemiological observations have shown a considerable decline in the mortality and morbidity of HIV-positive patients, which can be attributed to a reduction of HIV viral load and the recovery of immune function in previously ill subjects. ${ }^{50}$ Patients are protected to some extent against several oral lesion, i.e., candidosis, salivary gland disease, sarcoma, Kaposi's sarcoma, and oral hairy leukoplakia. ${ }^{51}$ The prevalence of all oral lesions has decreased by more than $30 \%$ since the introduction of HAART. ${ }^{52}$ For example, in a study conducted by Tukutuku et al. ${ }^{53}$ the prevalence of necrotizing ulcerative gingivitis (NUG) and periodontitis (NUP) before HAART was 17\%, and $16 \%$ of all lesions included these bacterial infections; nowadays the rates are lower at $10 \%$ for NUG and $5 \%$ for NUP. ${ }^{54}$ However, the prevalence of some oral lesions has nevertheless increased, such as HIV salivary gland disease, or remained the same, such as oral candidosis, aphtous ulcers, and Kaposi's sarcoma. ${ }^{55}$

The oral manifestations of AIDS in adults (Table 2) and children (Table 3) were classified before the advent of ART by EC-Clearinghouse. ${ }^{56-58}$ Although the EC-Clearinghouse classification was developed over a decade ago, there have been few new infections recognized in HIV-infected persons,

Table 2 - Classification of the oral manifestations of HIV disease in adults

\begin{tabular}{|c|c|c|}
\hline $\begin{array}{l}\text { Group } 1 \\
\text { lesions strongly associated with } \\
\text { HIV infection }\end{array}$ & $\begin{array}{l}\text { Group } 2 \\
\text { lesions less commonly associated with HIV infection }\end{array}$ & $\begin{array}{l}\text { Group } 3 \\
\text { lesions seen in HIV infection }\end{array}$ \\
\hline $\begin{array}{l}\text { Candidosis } \\
\text { - Erythematous } \\
\text { - Pseudomembranous }\end{array}$ & $\begin{array}{l}\text { Bacterial infections } \\
\text { - Mycobacterium avium-intracellulare } \\
\text { - Mycobacterium tuberculosis }\end{array}$ & $\begin{array}{l}\text { Bacterial infections } \\
\text { - Actinomyces israelii } \\
\text { - Escherichia coli } \\
\text { - Klebsiella pneumonia }\end{array}$ \\
\hline Hairy leukoplakia & Melanotic hyperpigmentation & Cat-scratch disease \\
\hline Kaposi's sarcoma & Necrotizing (ulcerative) stomatitis (Figure 5) & $\begin{array}{l}\text { Drug-reactions } \\
\text { - Ulcerative } \\
\text { - erythema multiforme } \\
\text { - lichenoid } \\
\text { - toxic epidermolysis }\end{array}$ \\
\hline Non-Hodgkin's lymphoma & $\begin{array}{l}\text { Salivary gland diseases } \\
\text { - Dry mouth due to decreased salivary flow rate } \\
\text { - Unilateral or bilateral swelling of major salivary glands }\end{array}$ & Epithelioid (bacillary) angiomatosis \\
\hline \multirow[t]{3}{*}{$\begin{array}{l}\text { Periodontal disease } \\
\text { - Linear gingival erythema } \\
\text { - Necrotizing gingivitis } \\
\text { - Necrotizing periodontitis }\end{array}$} & Thrombocytopenic purpura & $\begin{array}{l}\text { Fungal infections other than candida } \\
\text { - Cryptococcus neoformans } \\
\text { - Geotrichum candidum } \\
\text { - Histoplasma capsulatum } \\
\text { - Mucoraceae (mucormycosis, zygomycosis) } \\
\text { - Aspergillus flavus }\end{array}$ \\
\hline & Ulceration NOS (not otherwise specified) & $\begin{array}{l}\text { Neurological disturbances } \\
\text { - Facial palsy } \\
\text { - Trigeminal neuralgia }\end{array}$ \\
\hline & $\begin{array}{l}\text { Viral infections } \\
\text { - Herpes simplex virus } \\
\text { - Human papillomavirus lesions } \\
\text { Condyloma acuminatum } \\
\text { Focal epithelial hyperplasia } \\
\text { - Verruca vulgaris } \\
\text { - Varicella zoster virus } \\
\text { Herpes zoster } \\
\text { - Varicella }\end{array}$ & $\begin{array}{l}\text { Viral infections } \\
\text { - Cytomegalovirus } \\
\text { - Molluscum contagiosum }\end{array}$ \\
\hline
\end{tabular}


Table 3 - Classification of oral manifestations of pediatric HIV disease

\begin{tabular}{|c|c|c|}
\hline $\begin{array}{l}\text { Group } 1 \\
\text { lesions commonly associated with pediatric } \\
\text { HIV infection }\end{array}$ & $\begin{array}{l}\text { Group } 2 \\
\text { lesions less commonly associated with } \\
\text { pediatric HIV infection }\end{array}$ & $\begin{array}{l}\text { Group } 3 \\
\text { lesions strongly associated with HIV infection } \\
\text { but rare in children }\end{array}$ \\
\hline $\begin{array}{l}\text { Candidosis } \\
\text { - Erythematous } \\
\text { - Pseudomembranous } \\
\text { - Angular cheilitis }\end{array}$ & Seborrhoeic dermatitis & $\begin{array}{l}\text { Neoplasms } \\
\text { • Kaposi's sarcoma } \\
\text { - Non-Hodgkin's lymphoma }\end{array}$ \\
\hline Herpes simplex virus infection & $\begin{array}{l}\text { Bacterial infections of oral tissues } \\
\text { - Necrotizing (ulcerative) stomatitis }\end{array}$ & Oral hairy leukoplakia \\
\hline Linear gingival erythema & $\begin{array}{l}\text { Periodontal diseases } \\
\text { - Necrotizing (ulcerative) gingivitis } \\
\text { - Necrotizing (ulcerative) periodontitis }\end{array}$ & Tuberculosis-related ulcers \\
\hline Parotid enlargement & $\begin{array}{l}\text { Viral infections } \\
\text { - Cytomegalovirus } \\
\text { - Human papilloma virus } \\
\text { - Molluscum contagiosum } \\
\text { - Varicella-zoster virus } \\
\text { - Herpes zoster } \\
\text { - Varicella }\end{array}$ & \\
\hline $\begin{array}{l}\text { Recurrent aphthous ulcers } \\
\text { - Minor } \\
\text { - Major } \\
\text { - Herpetiform }\end{array}$ & Xerostomia & \\
\hline
\end{tabular}

perhaps reflecting the wide availability of HAART in the developed world. ${ }^{1}$

The frequency and presentation of some oral lesions associated with HIV infection will, and do, vary with the geography. Patients who do not receive ART are likely to still have the common oral features of HIV disease: candidosis (typically acute pseudomembranous candidosis), hairy leukoplakia, Kaposi's sarcoma, and perhaps periodontal disease. ${ }^{59}$ Tuberculosis is more likely in persons residing in or migrating from the developing world, while periodontal disease and other oral lesions due to the use of antiretroviral drugs seem to be most commonly reported in individuals in the developed world. ${ }^{60-62}$

\section{Fungal Infections}

\section{Oral Candidosis}

Candida albicans is the predominant yeast that colonizes the oral cavity of both healthy subjects and HIV-infected individuals in the developed and developing world. ${ }^{63}$ However, oral pseudomembranous candidosis (Figure 1) still remains the most common fungal infection of HIV disease; it has been associated with more frequent progression of HIV to AIDS and has been also used as a clinical marker to define the severity of HIV infection, ${ }^{64}$ with pseudomembranous candidosis usually followed by erythematous candidosis.

Candidal infection has been reported in adults, with a prevalence varying from 1.5 to $56 \%,{ }^{65}$ with the higher

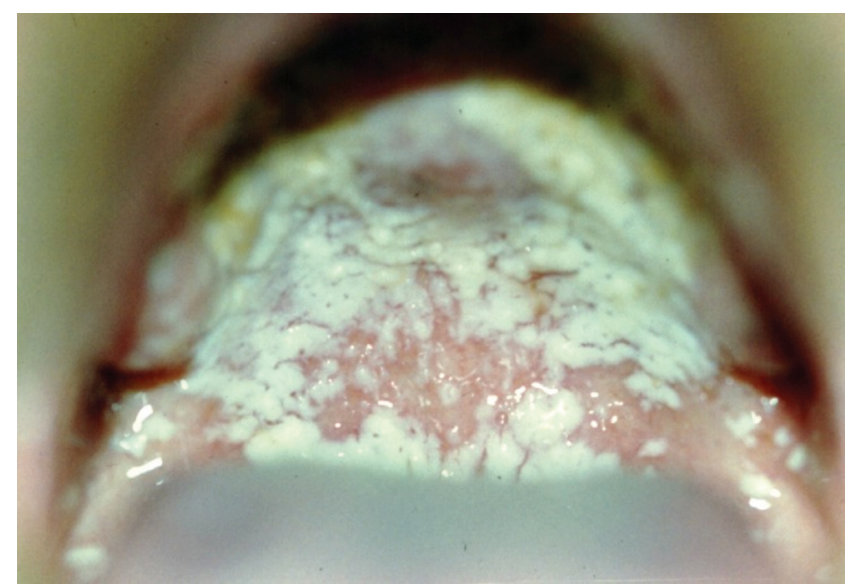

Figure 1 - Severe pseudomembranous candidosis (Thrush) in HIV disease

prevalence rates in the developing world. ${ }^{65}$ The wide variability in the prevalence of oral candidosis may be attributed to a variety of factors including the sociodemographic and clinical characteristics of the study group and the diagnostic methods employed. ${ }^{47}$ Pseudomembraneous candidosis (PC) is the most common clinical presentation of all candidal infections (ranging from 55.8 to $69.7 \%$ ), followed by erythematous candidosis (EC) (25.7-50\%), angular cheilitis (13.7-27.1\%), and hyperplastic candidosis $(0-1.7 \%)^{66,67}$

Among children in the developed and developing world, rates of oral candidosis have been described as varying from 22.5 to $83.3 \%{ }^{68} \mathrm{PC}$ infection seems to be the most prevalent form in children ${ }^{69}$ followed by $\mathrm{EC},{ }^{70}$ and then angular 
cheilitis as the third most prevalent. ${ }^{71}$ However, EC has been occasionally reported to be more prevalent than PC. ${ }^{72}$

The improvement in the immune system of patients receiving HAART may explain the reduction in the prevalence of this opportunistic infection in these groups of HIV-infected individuals. The frequency of oral candidosis usually correlates with a falling CD4+ T lymphocyte count and a rising HIV viral load. ${ }^{73}$

Other factors that have been implicated in the predisposition of HIV patients to oral candidal infection are age under 35 years, injection drug use, and smoking more than 20 cigarettes a day. ${ }^{47}$ In contrast, some recent studies have not revealed any specific features that may predispose these patients to oral candidosis. ${ }^{74}$

\section{Viral Infections}

\section{Oral hairy leukoplakia}

Oral hairy leukoplakia (OHL) is a clinical manifestation of Epstein-Barr virus (EBV) infection almost exclusively found in patients with untreated advanced HIV disease and typically occurs on the lateral border of the tongue of HIV-infected individuals and other groups of immunocompromised individuals (Figure 2). ${ }^{75}$ The prevalence of OHL in recent studies of HIV-infected adults varies from 0.42 to $38 \%$ in both developed and developing countries. ${ }^{76-78}$ The increased prevalence of OHL might be related to a higher exposure to $\mathrm{EBV},{ }^{79} \mathrm{a}$ lower $\mathrm{CD} 4+$ count, and a higher HIV viral load. ${ }^{80}$

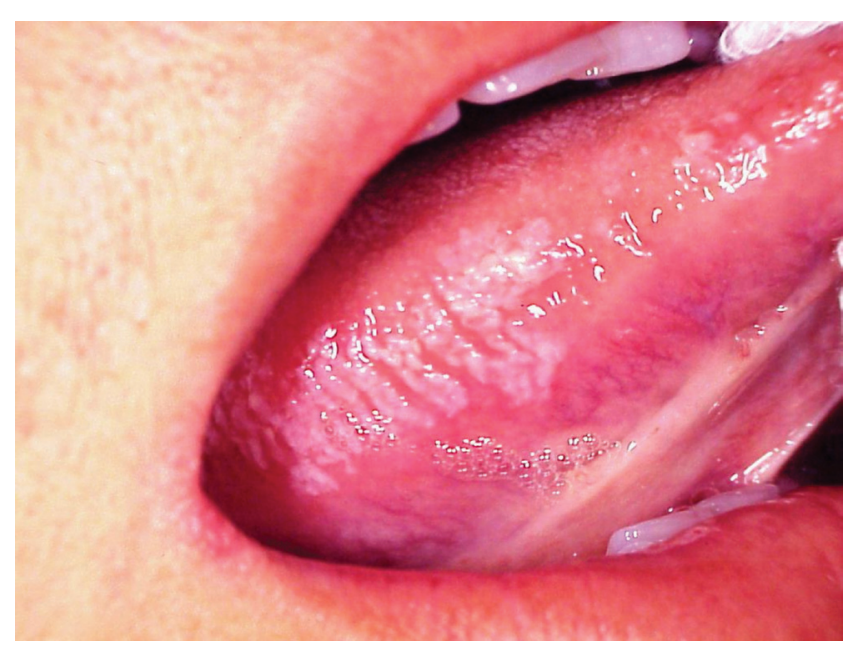

Figure 2 - Oral hairy leukoplakia - this finding can also be a feature of iatrogenic immunosuppression

Because OHL is asymptomatic and has no malignant potential, it rarely requires treatment. Nevertheless, acyclovir, and more recently valacyclovir, has been used for the treatment of OHL; unfortunately, acyclovir resistance can prevent the clinical resolution of OHL. ${ }^{81}$ As discussed previously, most but not all, relevant studies have observed that the frequency of OHL falls with HAART, thus further adding to the rationale that there is little if any need for active intervention in OHL. ${ }^{82}$

\section{Oral Kaposi's sarcoma}

Kaposi's sarcoma (KS) is a malignant, multifocal systemic disease that originates from the vascular endothelium and has a variable clinical course. KS is caused by human herpes virus 8 (HHV-8), which is transmitted sexually or via blood or saliva. ${ }^{83}$ The most frequently involved site is the skin, but mucous membranes, the lymphatic system, and viscera, in particular the lung and gastrointestinal tract, can also be involved. ${ }^{84}$ In patients with HIV disease, KS usually arises when the CD4+ T cell count is less than $200{ }^{85}$

The prevalence of oral Kaposi's sarcoma of the mouth varies from 0 to $12 \%$ in Africa and 0 to $38 \%$ in US and Europe. However, differences in the frequency of both oral and non-oral KS in HIV disease between the developed and developing world are likely to exist. ${ }^{86}$ In the developed world, the incidence of HIV-related KS began to decline from 25.6 cases per 1000 person-years (95\% confidence interval $[\mathrm{CI}], 21.8-29.9)$ in the early 1990 s to an average incidence of 7.5 per 1000 person-years (95\% CI, 3.4-16.7) in 1996 and $1997^{87}$ before HAART became available; this trend became more pronounced thereafter. In contrast, the prevalence of KS has risen alarmingly during this same time period in Africa ${ }^{88}$ Since the advent of AIDS, KS has become more frequent in both genders, and the male to female ratio has changed from 19:1 to 1.7:1, particularly in East Africa. Recently, the high prevalence of oral KS was demonstrated by the observation that $18.6 \%$ of a group of HIV-infected patients in Zimbabwe and from 6 to 14\% of another group of patients in the same region had oral KS. ${ }^{89}$

Oral KS manifests as red to purple macules, papules, or nodules that may ulcerate and cause local tissue destruction (Figure 3).$^{90}$ The palate and gingivae are the most commonly affected intraoral sites. In HIV disease, the oral cavity is commonly affected and is the first clinical site of KS in $20 \%$ of cases, while it occurs concomitantly with skin and visceral involvement in up to $70 \%$ of patients. ${ }^{92}$

At present, there is no preventive vaccine or antiviral agent for AIDS-related KS. Treatment is thus directed towards the elimination or at least reduction of cosmetically unacceptable lesions, the reduction of painful or unsightly edema or lymphadenopathy, as well as the relief of symptoms caused by visceral involvement. ${ }^{93}$ Local therapy may be effective for limited disease, but systemic therapy is required for disseminated KS. ART is useful in the management of HIV-related KS because it reduces the HIV viral load 


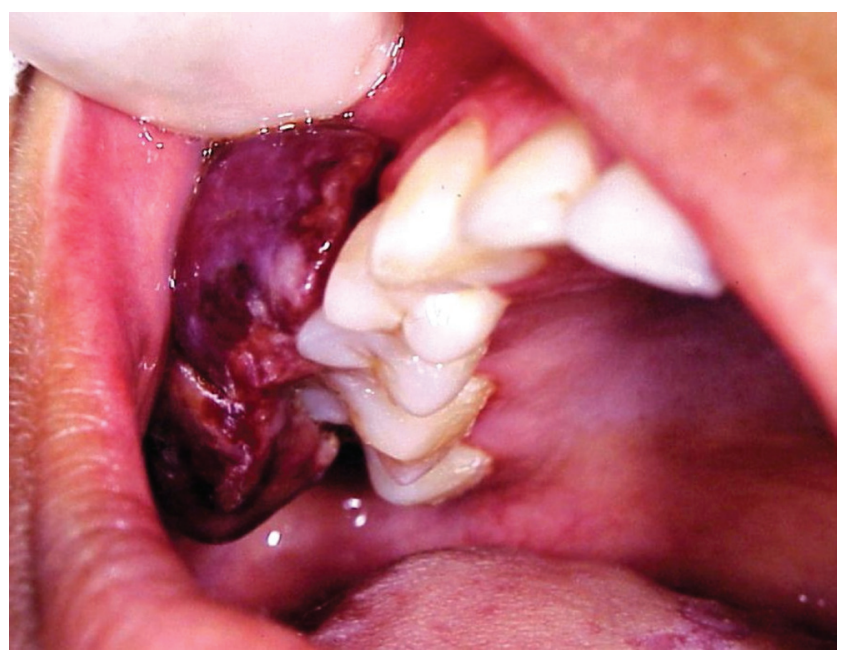

Figure 3 - Kaposi's sarcoma of the right buccal vestibule in an undiagnosed HIV-infected patient

and raises the CD4+ T cell count, both of which indirectly contribute to the pathogenesis of KS..$^{90}$ Older approaches for oral KS have included local radiation, ${ }^{93}$ laser therapy, ${ }^{94}$ surgical excision, and cytotoxic therapy with vinca alkaloids (vinblastine, vincristine and vinorelbine) and bleomycin. ${ }^{95}$ However, only five agents are currently approved by the FDA for the treatment of KS: alitretinoin gel for topical therapy and liposomal daunorubicin and oloxorubucin, paclitaxel, and interferon-alpha for systemic therapy. ${ }^{91,96}$

\section{Human Papillomavirus (HPV)}

The reported increased prevalence of oral condylomas since the widespread administration of HAART suggests that a drug or combination of drugs used to treat HIV may be a risk factor for oral HPV infection. ${ }^{97}$ However, HPV infection has taken on much greater significance in recent years because the frequency of HPV infection has increased in groups examined following the introduction of HAART and especially because this virus may be of etiological significance in the development of oral squamous cell carcinoma (OSCC) [reviewed in detail elsewhere]. ${ }^{98}$

HIV-infected individuals may be more likely to carry HPV in the mouth than immunocompetent individuals are ( 25.3 vs. $7.6 \%$, respectively). They are also more likely to be infected by more than one HPV genotype (5.8 vs. $1.5 \%$ ) and carry a high-risk genotype, such as HPV-16. Oral warts are uncommon in immunocompetent individuals but oral mucosal abnormalities such as papillomas are more likely to arise in those HPV-infected individuals with concomitant HIV disease. ${ }^{97}$ Oral HPV infection (both the carriage and/or clinical presentation) seems to be associated with male gender, HSV-2 seropositivity, and older age in HIVseronegative individuals. In HIV-infected populations, the risk factors for oral HPV infection still include male sex and
HSV-2 serostatus, but the strongest association is with oralgenital contact. ${ }^{99}$

The etiology of the high prevalence of oral HPV infection in HIV-infected individuals is unclear. It is possible that HIV-infected individuals exhibiting high-risk sexual practices frequently acquire oral HPV infection due to multiple exposures simply as a side effect of these high-risk practices. Alternatively, the high rates of HPV detection could be due to increased HPV replication and/or persistence rather than increased HPV acquisition. If persistence of oral HPV leads to HPV-related disease, as it does in the genital tract, increased persistence of HPV could also explain the increased prevalence of oral warts in HAART-treated HIV-positive individuals. ${ }^{100}$ It is also possible that the individuals who are placed on HAART have already been immunosuppressed long enough to surpass some critical threshold for developing HPV-related disease that cannot be then reversed with therapy. ${ }^{101}$

\section{Gingival and Periodontal Diseases}

\section{Gingivitis and Periodontitis}

Gingival and periodontal disease is common in HIV infection, particularly in individuals residing in or who have migrated from the developing world. The gingival and periodontal diseases associated with HIV include linear gingival erythema, NUG (Figure 4), NUP, and necrotizing stomatitis. ${ }^{102}$

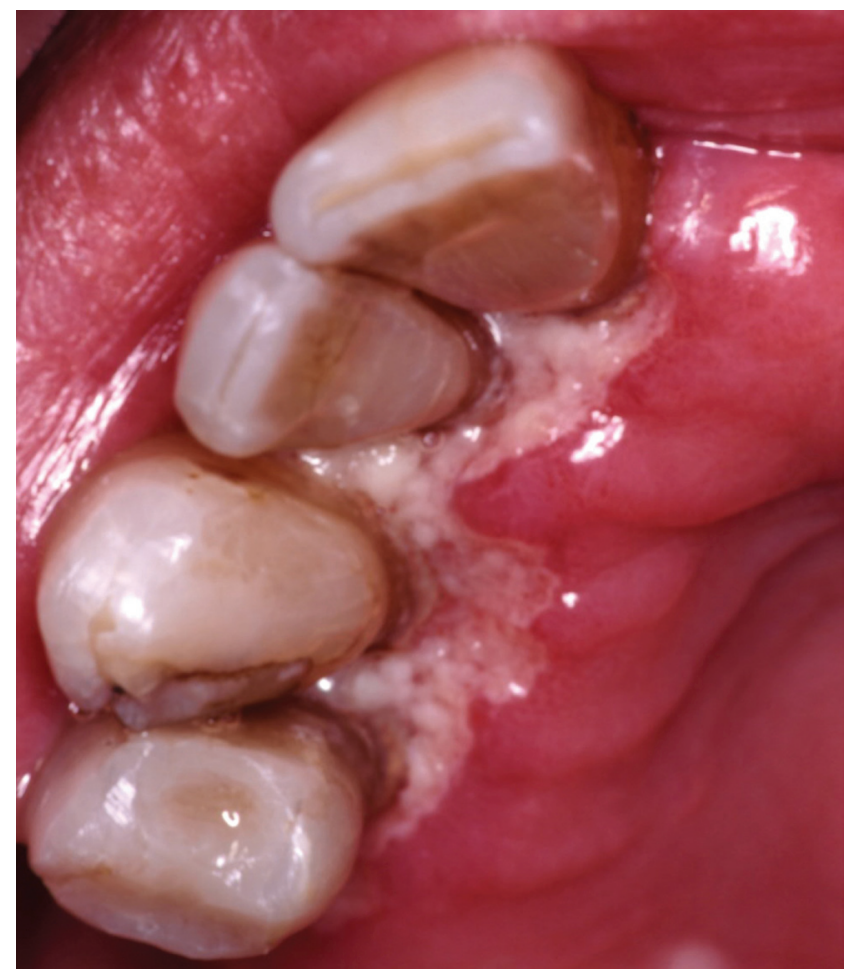

Figure 4 - Necrotizing gingivitis in HIV disease 
Nevertheless, the most common gingival and periodontal features of HIV-infected persons are plaque related to gingivitis and chronic periodontitis, similar to that found in non-HIV-infected individuals. "Chronic" periodontal disease has been described to be more common and/or more aggressive in HIV-infected patients. ${ }^{103}$

The possible occurrence of HIV-specific periodontal disease has been observed in some but not all groups of HIV-infected patients, suggesting that HIV infection alone does not predispose patients to pocketing, attachment loss, or bleeding on probing. ${ }^{104}$ The reported prevalence of HIV-related gingival and periodontal disease (excluding opportunistic infections and malignancy) varies from 0 to $47 \%$ in adults ${ }^{105}$ and from 0 to $20 \%$ in children; NUG and NUP are less prevalent, varying from 2.2 to $5 \% .{ }^{106}$ Although aspects of HIV-induced immunosuppression have been proposed as the likely cause of HIV-related gingival and periodontal disease, HIV-infected patients often have other relevant risk factors, such as tobacco smoking and poor oral hygiene, and these factors alone can explain the increased prevalence of the disease. ${ }^{107}$

\section{HIV-related salivary gland disease}

\section{Salivary gland enlargement}

HIV-associated salivary gland disease (HIV-SGD) is characterized by salivary gland swelling in one or both parotid glands with or without xerostomia. ${ }^{75}$ In some patients, salivary gland enlargement may be the first clinical manifestation of HIV infection. Inflammatory/infectious conditions are the second most common group of salivary gland disorders in HIV disease, followed by neoplastic lesions. ${ }^{108}$

Salivary gland enlargement occurs in approximately 3 to $0 \%$ of adult patients infected with HIV, with a higher frequency in children, and it may be the first clinical manifestation of HIV. The swelling arises as a consequence of a variety of etiologies, including reactive/inflammatory conditions, infections, and neoplasms. ${ }^{109}$

Typically, the parotid gland is affected, and the swelling is bilateral, sometimes cystic, and seen in association with generalized lymphadenopathy, persistent circulating CD8+ lymphocytosis and diffuse visceral CD8+ lymphocytic infiltration. This symptom complex is termed diffuse infiltrative (CD8) lymphocytosis syndrome (DILS). ${ }^{110,111}$

In other cases, the swelling can be caused by benign parotid hypertrophy or cystic benign lymphoepithelial lesions (BLLs). These cysts may originate from an HIVrelated reactive lymphoproliferation of glandular epithelium trapped in normal intraparotid lymph nodes remaining from embryologic development or from a ductal obstruction of

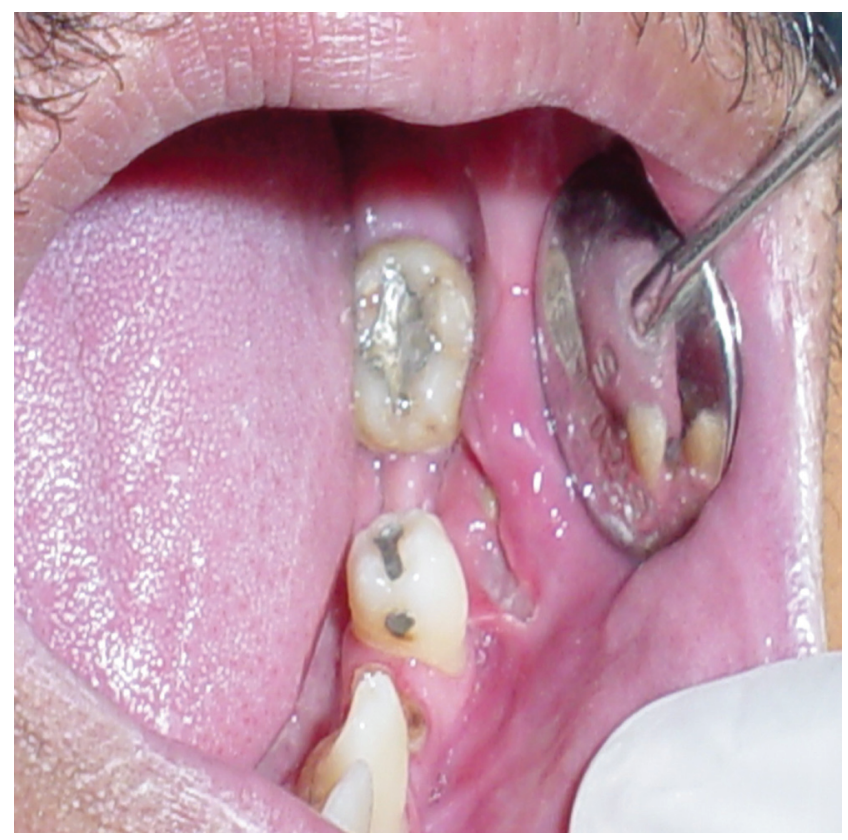

Figure 5 - Necrotic oral mucosal ulceration, possibly associated with CMV in severe HIV disease

lymphoid proliferation leading to ductal dilatation. ${ }^{12}$

Inflammatory or infectious conditions are the second most common group of salivary gland disorders in HIV disease, followed by neoplastic lesions. Indeed, HIVinfected patients have a high incidence of salivary NHL and secondary malignant neoplasms (e.g., Kaposi's sarcoma) accounting for $10 \%$ of malignant salivary gland neoplasms in HIV disease. ${ }^{108}$

Xerostomia is a common symptom in HIV-infected individuals, and it has many potential causes. For example, it may accompany salivary gland enlargement in DILS, ${ }^{113}$ and it has also been reported to occur with HAART particularly some of the NRTIs and PIs. ${ }^{114}$ Antiretroviral agents such as lamivudine, didanosine (DDI) and the protease inhibitors can cause reduced salivary output. In addition, the long-term use of other non-HIV-related medications, such as many classes of antidepressants, can also lead to oral dryness. ${ }^{115}$

Treatment of salivary gland enlargement in HIV disease remains non-specific. While the frequency of HIV-SGD may increase with HAART, it occasionally resolves with HAART. Superficial parotidectomy has been advocated to alleviate the HIV-associated parotid swelling, but its application may be limited because of associated morbidity. Aspiration of cystic lesions can be of some transient benefit, and injections of tetracycline and doxycycline have minimal success due the presence of multiple cysts. ${ }^{116}$ Benign parotid hypertrophy in HIV disease can be treated with external radiation therapy ( 24 Gy in 1.5 Gy daily fractions), with significant improvements in cosmetic control and long-term results. ${ }^{117}$ 


\section{Xerostomia}

In general dental practice, many patients complain of xerostomia, typically secondary to drug therapy (particularly antidepressants and anxiolytics) ${ }^{118}$ but sometimes a sign of Sjogren's syndrome. ${ }^{119}$ However, if a patient is known to have HIV disease, the xerostomia likely reflects HIV salivary gland disease or is an adverse side effect of ART. ${ }^{120}$ All patients with xerostomia regardless of HIV serostatus must be given appropriate advice regarding the increased risk of caries (particularly cervical and root caries) and gingival inflammation. In addition, salivary substitutes and sialogogues may lessen the symptoms of xerostomia. ${ }^{121}$

\section{Neoplastic tumors}

\section{Non-Hodgkin's lymphoma}

Non-Hodgkin's lymphoma (NHL) is the second most common HIV-associated tumor. As with $\mathrm{KS}$, the frequency of this tumor has fallen with the introduction of ART; however, it is still a very common tumor of HIV-infected individuals in the developing world. ${ }^{122}$

A variety of NHLs can arise in the mouth in HIV disease; in fact, a rare type called plasmablastic lymphoma seems to nearly always arise exclusively in the mouth. ${ }^{123}$ The oral manifestations of NHL include soft tissue masses with or without ulceration and tissue necrosis, usually involving the gingival, palatal, and alveolar mucosa. The optimal treatment for HIV-associated NHL remains unclear. However, oral NHL management primarily entails systemic therapy ${ }^{124}$ with intensive high-dose chemotherapy and autologous stem cell transplantation; this latter treatment has resulted in sustained complete remissions in selected patients with recurrent chemosensitive disease. ${ }^{25}$

\section{DENTAL CONSIDERATIONS FOR PEDIATRIC HIV PATIENTS}

The oral manifestations of HIV infection in children are generally similar to those in adults, but there are some differences particularly with regards to caries and possibly the eruption times of teeth. HIV-infected children may be more vulnerable to dental caries, affecting both the deciduous and permanent dentition, than healthy subjects. However, the caries in HIV-infected children appear to be largely similar to those in other chronically sick children of comparable age. ${ }^{126}$
Children with HIV disease may exhibit a different decay pattern than healthy children, possibly related to HIV-associated xerostomia. ${ }^{127,128}$ Part of the increase in caries in HIV-infected children may be attributed to the high carbohydrate and sugar intake required to prevent or treat any failure to thrive and to the ingestion of sucrose-based medications (particularly antibiotics and antifungals, but also antiretrovirals such as zidovudine.) $)^{129}$

In the developing world, poverty and lack of fluoride supplements may also contribute to an increased risk of dental caries in children with HIV disease. ${ }^{130}$ Both delayed and accelerated eruption of permanent teeth and overretention of primary teeth have been observed in some HIVinfected children. ${ }^{130}$ The accelerated eruption pattern may be related to concurrent or previous dental and periodontal disease, but the exact cause of delayed eruption of teeth is unknown; the poor general health status of some children, particularly when there is malnutrition, may be an important co-factor. $^{72}$

\section{CONCLUSIONS}

An understanding of the immunopathogenesis of HIV infection is a major prerequisite for rationally improving therapeutic strategies and developing immunotherapeutics and prophylactic vaccines. A better understanding of the oral manifestations of HIV/AIDS in both adults and children has implications for all dental health care workers in the world. We must assume that it is almost impossible to recognize if patients have, or are liable to have, HIV infection, and this knowledge must be reflected in the maintenance and continued updating of infection control policies in clinical practice. For that reason, it is necessary to integrate continuous and careful medical care of oral health as a part of the treatment for people with HIV/AIDS. The prevention, diagnosis, treatment, and control of these oral manifestations should be part of the objectives of every dental health professional; these professionals should hereafter also be informed about the relationship between immunological markers and the appearance of oral lesions. Key elements of the response to the HIV/AIDS epidemic include the support of the World Universal Public Health System, the provision of universal access to highly active antiretroviral therapy, and the creation of harm reduction projects that are politically and financially supported by federal governments.

\section{REFERENCES}

1. Frezzini C, Leao JC, Porter S. Current trends of HIV disease of the mouth. J Oral Pathol Med. 2005;34:513-31.
2. Ascher MS, Sheppard HW. AIDS as immune system activation: a model for pathogenesis. Clin Exp Immunol 1988;73:165-7. 
3. Health protection agency. Evidence of continuing increase in the HIV prevalence among injecting drug users in England and Wales. CDR Weekly. 2006; 16:51.

4. UNAIDS. Report on the Global AIDS epidemic 2007. WHO 2007.

5. NACO - National AIDS Control Organization (2004). Combating HIV/ AIDS in India. October 2003. Available from: <http://www.nacoonline. org $>$.

6. UNAIDS. UNAIDS and the Joint United Nations Programme on HIV/ AIDS. Children and AIDS: Second stocktaking report. Actions and progress. April 2008.

7. Kamps BS; Hofmann C. In: Hoffmann C, Rockstroh JK; Kamps BS. HIV Medicine 2007; Flying Publisher 15th Edition; p. 28. Avalilable from <www.HIVMedicine.com>.

8. Horowitz HW, Telzak EE, Sepkowitz KA, Wormser GP. Human immunodeficiency virus infection, Part I. Dis Mon. 1998;44:545606.

9. Rothenberg RB, Scarlett M, del Rio C, Reznik D, O’Daniels C. Oral transmission of HIV. AIDS. 1998;12:20:95-105.

10. Najioullah F, Barlet V, Renaudier P, Guitton C, Crova P, Guérin JC, et al. Failure and success of HIV tests for the prevention of HIV-1 transmission by blood and tissue donations. J Med Virol. 2004;73:3479 .

11. Metsch LR, Pereyra M, Purcell DW, Latkin CA, Malow R, Gómez CA, et al. Correlates of lending needles/syringes among HIV-seropositive injection drug users. J Acquir Immune Defic Syndr 2007;1;46 Suppl 2:S72-9.

12. Salvatori F, De Martino M, Galli L, Vierucci A, Chieco-Bianchi L, De Rossi A. Horizontal transmission of human immunodeficiency virus type 1 from father to child. AIDS Res Hum Retroviruses. 1998;14:167985 .

13. French MA, Herring BL, Kaldor JM, Sayer DC, Furner V, de Chaneet $\mathrm{CC}$, et al. Intrafamilial transmission of HIV-1 infection from individuals with unrecognized HIV-1 infection. AIDS. 2003;17:1977-81.

14. Fraser VJ, Powderly WG. M. Risks of HIV infection in the health care setting. Annual Review of Medicine. 1995;46:203-11.

15. Marcus R, Kay K, Mann JM. Transmission of human immunodeficiency virus (HIV) in health-care settings worldwide. Bull World Health Organ. 1989;67:577-82.

16. Scully C, Porter S. HIV topic update: oro-genital transmission of HIV. Oral Dis. 2000;:92-8.

17. Campo J, Perea MA, del Romero J, Cano J, Hernando V, Bascones A. Oral transmission of HIV, reality or fiction? An update. Oral Dis. 2006; $12: 219-28$

18. Stahl-Hennig C, Steinman RM, Tenner-Racz K, Pope M, Stolte N, Mätz-Rensing K, et al. Rapid infection of oral mucosal-associated lymphoid tissue with simian immunodeficiency virus. Science. 1999;285:1261-5.

19. Scully C, Greenspan JS. Human immunodeficiency virus (HIV) transmission in dentistry. J Dent Res. 2006;85:794-800.

20. The Lancet. Risk of HIV transmission during dental treatment [editorial]. Lancet. 1992;340:1259-60.

21. Health protection agency. Eye of the needle. Surveillance of Significant Occupational Exposure to Bloodborne Viruses in Health Care Workers. Centre for Infections; England, Wales and Northern Ireland Seven Year Report: January 2005:1-26

22. Moutsopoulos NM, Greenwell-Wild T, Wahl SM. Differential mucosal susceptibility in HIV-1 transmission and infection. Adv Dent Res. 2006;19:52-6.

23. Chua AC, Leo YS, Lee CC. Building partnerships to address the HIV epidemic. Singapore Med J 2008; 49(5):376-9.

24. Medley GF, Billard L, Cox DR, Anderson RM. The distribution of the incubation period for the acquired immunodeficiency syndrome (AIDS). Proc R Soc Lond B Biol Sci. 1988;233:367-77.

25. Cooper DA, Gold J, Maclean P, Donovan B, Finlayson R, Barnes TG, et al. Acute AIDS retrovirus infection. Definition of a clinical illness associated with seroconversion. Lancet. 1985;1:537-40.

26. Miró JM, Sued O, Plana M, Pumarola T, Gallart T. Advances in the diagnosis and treatment of acute human immunodeficiency virus type 1 (HIV-1) infection. Enferm Infecc Microbiol Clin. 2004;22:643-59.
27. Jeeninga RE, Westerhout EM, van Gerven ML, Berkhout B. HIV1 latency in actively dividing human $\mathrm{T}$ cell lines. Retrovirology. 2008;5:37.

28. Han Y, Wind-Rotolo M, Yang HC, Siliciano JD, Siliciano RF: Experimental approaches to the study of HIV-1 latency. Nat Rev Microbiol. 2007,5:95-106

29. Kahn JO, Walker BD. Acute human immunodeficiency virus type 1 infection. New England Journal of Medicine. 1998,339:33-39.

30. Greenspan D, Komaroff E, Redford M, Phelan JA, Navazesh M, Alves ME, et al. Oral mucosal lesions and HIV viral load in the Women's Interagency HIV Study (WIHS). J Acquir Immune Defic Syndr. 2000;25:44-50

31. Coogan MM, Greenspan J, Challacombe SJ. Oral lesions in infection with human immunodeficiency virus. Bull World Health Organ. 2005;83:700-6.

32. Challacombe S. Revised classification of HIV--associated oral lesions. Br Dent J. 1991. 20;170:305-6.

33. Coulter ID, Heslin KC, Marcus M, Hays RD, Freed J, Der-Martirosia $\mathrm{C}$, et al. Associations of self-reported oral health with physical and mental health in a nationally representative sample of HIV persons receiving medical care. Qual Life Res. 2002;11:57-70.

34. Stevenson M. HIV-1 pathogenesis. Nat Med. 2003;9:853-60.

35. Scully C, Dios P. Orofacial effects of antiretroviral therapies. Oral Diseases 2001; 7(4):205-210.

36. d'Arminio Monforte A, Sabin CA, Phillips A, Sterne J, May M, Justice $\mathrm{A}$, et al. The changing incidence of AIDS events in patients receiving highly active antiretroviral therapy. Arch Intern Med. 2005;28;165:41623. Erratum in: Arch Intern Med 2005;165:1200.

37. Hoffmann C, Mulcahy F. In: Hoffmann C, Rockstroh JK, Kamps BS. HIV Medicine 2007; Flying Publisher 15th Edition; p. 89. Avalilable from <www.HIVMedicine.com>.

38. Williams IG. Enfuvirtide (Fuzeon): the first fusion inhibitor. Int J Clin Pract 2003;57:890-7.

39. Aleman S, Soderbarg K, Visco-Comandini U, Sitbon G; Sonnerborg A. Drug resistance at low viraemia in HIV-1-infected patients with antiretroviral combination therapy. Clinical Science. AIDS. 2002:16:1039-44

40. Tang JW, Pillay D. Transmission of HIV-1 drug resistance. J Clin Virol. 2004; 30:1-10.

41. James J, Carruthers A, Carruthers J. HIV-associated facial lipoatrophy. Dermatol Surg. 2002;28:979-86.

42. Stankov MV, Behrens GM. HIV-therapy associated lipodystrophy: experimental and clinical evidence for the pathogenesis and treatment. Endocr Metab Immune Disord Drug Targets. 2007;7:237-49.

43. Orlando G, Guaraldi G, De Fazio D, Rottino A, Grisotti A, De Santis G, et al. Long-term psychometric outcomes of facial lipoatrophy therapy: forty-eight-week observational, nonrandomized study. AIDS Patient Care STDS. 2007;21:833-42.

44. Hodgson TA, Rachanis CC. Oral fungal and bacterial infections in HIVinfected individuals: an overview in Africa. Oral Dis. 2002;8:80-7.

45. Wood R.Management of HIV and AIDS in the African context. Oral Dis. 2002;8 Suppl 2:32-3.

46. Barasch A, Safford MM, Dapkute-Marcus I, Fine DH. Efficacy of chlorhexidine gluconate rinse for treatment and prevention of oral candidiasis in HIV-infected children: a pilot study. Oral Surg Oral Med Oral Pathol Oral Radiol Endod. 2004;97:204-7.

47. Campo J, Del Romero J, Castilla J, Garcia S, Rodriguez C, Bascones A. Oral candidiasis as a clinical marker related to viral load, CD4 lymphocyte count and CD4 lymphocyte percentage in HIV-infected patients. J Oral Pathol Med. 2002;31:5-10.

48. Johnson VA, Brun-Vezinet F, Clotet B, Conway B, Kuritzkes DR, Pillay D, et al. Update of the Drug Resistance Mutations in HIV-1: 2005.Top HIV Med. 2005;13:51-7.

49. Sroussi HY, Epstein JB.Changes in the pattern of oral lesions associated with HIV infection: implications for dentists. J Can Dent Assoc. 2007:73:949-52.

50. Sterne JA, Hernán MA, Ledergerber B, Tilling K, Weber R, Sendi P, et al. Long-term effectiveness of potent antiretroviral therapy in preventing AIDS and death: a prospective cohort study. Lancet. 2005;366:378-84. 
51. Porter SR, Scully C. HIV topic update: protease inhibitor therapy and oral health care. Oral Dis. 1998;4:159-63.

52. Ceballos-Salobrena A, Gaitan-Cepada LA, Ceballos-Carcia L, LezemaDel Valle D. Oral lesions in HIV/AIDS patients undergoing highly active antiretroviral treatment including protease inhibitors: a new face of oral AIDS? AIDS Patients Care STDS. 2000;14:627-35.

53. Tukutuku K, Muyembe-Tamfum L, Kayembe K, Odio W, Kandi K, Ntumba M. Oral manifestations of AIDS in a heterosexual population in a Zaire hospital. J Oral Pathol Med. 1990;19:232-4.

54. Reichart PA. Oral manifestations in HIV infection: fungal and bacterial infections, Kaposi's sarcoma. Med Microbial Immunol. 2003;192:165-69.

55. Patton LL, McKaig R, Strauss R, Rogers D, Eron JJ Jr. Changing prevalence of oral manifestations of human immuno-deficiency virus in the era of protease inhibitor therapy. Oral Surg Oral Med Oral Pathol Oral Radiol Endod. 2000;89:299-304.

56. EC-Clearinghouse on oral problems related to HIV infection and WHO collaborating centre on oral manifestations of the human immunodeficiency virus. Classification and diagnostic criteria for oral lesions in HIV infection. J Oral Pathol Med. 1993;22:289-91.

57. Ramos-Gomez F, Flaitz C, Catapano P. Classification, diagnostic criteria, and treatment recommendations for orofacial manifestations in HIV-infected paediatric patients. J Clin Pediatr Dent. 1999;23:85-96.

58. Flint S, Glick M, Patton L, Tappuni A, Shirlaw P, Robinson P. Consensus guidelines on quantifying HIV related oral mucosal disease. Oral Dis. 2002; 8(Suppl. 2):115-9.

59. Tappuni AR, Fleming GJ. The effect of antiretroviral therapy on the prevalence of oral manifestations in HIV-infected patients: a UK study. Oral Surg Oral Med Oral Pathol Oral Radiol Endod. 200;92:623-8.

60. Patton LL, Phelan JA, Ramos-Gomez FJ, Nittayananta W, Shiboski $\mathrm{CH}$, Mbuguye TL. Prevalence and classification of HIV-associated oral lesions. Oral Dis. 2002; 8(Suppl. 2):98-109.

61. Reichart PA. Infections of the mouth mucosa (I). HIV infection an epidemiological, clinical and therapeutic update. Mund Kiefer Gesichtschir. 1999;3: 236-41.

62. Blignaut E, Messer S, Hollis RJ, Pfaller MA. Antifungal susceptibility of South African oral yeast isolates from HIV/AIDS patients and healthy individuals. Diagn Microbiol Infect Dis. 2002;44:169-74.

63. Chidzonga MM, Mwale M, Malvin K, Martin JN, Greenspan JS, Shiboski CH. Oral candidiasis as a marker of HIV disease progression among Zimbabwean women. J Acquir Immune Defic Syndr. 2008;47:579-84.

64. Ranganathan K, Hemalatha R. Oral lesions in HIV infection in developing countries: an overview. Adv Dent Res. 2006;19:63-8.

65. Muzyka BC, Kamwendo L, Mbweza E, Lopez NB, Glick M, Matheson $\mathrm{PB}$, et al. Prevalence of HIV-1 and oral lesions in pregnant women in rural Malawi. Oral Surg Oral Med Oral Pathol Oral Radiol Endod. 2001;92:56-61.

66. Bendick C, Scheifele C, Reichart PA. Oral manifestations in 101 Cambodians with HIV and AIDS. J Oral Pathol Med. 2002;31:1-4.

67. Chidzonga MM. HIV/AIDS orofacial lesions in 156 Zimbabwean patients at referral oral and maxillofacial surgical clinics. Oral Dis. 2003;9:317-22.

68. Naidoo S, Chikte U. Oro-facial manifestations in paediatric HIV: a comparative study of institutionalized and hospital outpatients. Oral Dis. 2004;10:13-8.

69. Pongsiriwet S, Iamaroon A, Kanjanavanit S, Pattanaporn K, Krisanaprakornkit S. Oral lesions and dental caries status in perinatally HIV-infected children in Northern Thailand. Int J Paediatr Dent. 2003;13:180-5.

70. Fonseca R, Cardoso AS, Pomarico I. Frequency of oral manifestations in children infected with human immunodeficiency virus. Quintessence Int. 2000; 31:419-22.

71. Magalhães MG, Bueno DF, Serra E, Gonçalves R. Oral manifestations of HIV positive children. J Clin Pediatr Dent. 2001;25:103-6.

72. Khongkunthian P, Grote M, Isaratanan W, Piyaworawong S, Reichart PA. Oral manifestations in 45 HIVpositive children from Northern Thailand. J Oral Pathol Med. 2001;30:549-52.

73. Butt FM, Vaghela VP, Chindia ML. Correlation of CD4 counts and CD4/CD8 ratio with HIV-infection associated oral manifestations. East Afr Med J. 2007; 84:383-8.
74. Nittayananta W, Chanowanna N, Sripatanakul S, Winn T. Risk factors associated with oral lesions in HIVinfected heterosexual people and intravenous drug users in Thailand. J Oral Pathol Med. 2001;30:224 30 .

75. Lin HC, Corbet EF, Lo EC. Oral mucosal lesions in adult Chinese. J Dent Res 2001;80:1486-90.

76. Arendorf T, Holmes H. Oral manifestations associated with human immunodeficiency virus (HIV) infection in developing countries - are there differences from developed countries? Oral Dis. 2000;6:133-5.

77. Greenspan JS, Greenspan D. The epidemiology of the oral lesions of HIV infection in the developed world. Oral Dis. 2002;8(Suppl. 2):349.

78. Patton L, Hill C. Sensitivity, specificity, and positive predictive value of oral oppurtunistic infections in adults with HIV/AIDS as markers of immune suppression and viral burden. Oral Surg Oral Med Oral Pathol Oral Radiol Endod. 2004;90:182-8.

79. Rahman MA, Kingsley LA, Breinig MK, Ho M, Armstrong JA, Atchison RW, et al. Enhanced antibody responses to Epstein-Barr virus in HIV-infected homosexual men. J Infect Dis. 1989;159:472-9.

80. Eyeson JD, Tenant-Flowers M, Cooper DJ, Johnson NW, Warnakulasuriya KA. Oral manifestations of an HIV positive cohort in the era of highly active antiretroviral therapy (HAART) in South London. J Oral Pathol Med. 2002;31:169-74.

81. Walling DM, Flaitz CM, Nichols CM, Hudnall SD, Adler-Storthz K. Persistent productive Epstein-Barr virus replication in normal epithelial cells in vivo. J Infect Dis. 2001;184:1499-507.

82. Walling DM, Flaitz CM, Nichols CM. Epstein-Barr virus replication in oral hairy leukoplakia: response, persistence, and resistance to treatment with valacyclovir. J Infect Dis. 2003;188:883-90.

83. Martró E, Esteve A, Schulz TF, Sheldon J, Gambús G, Muñoz R, et al. Risk factors for human Herpesvirus 8 infection and AIDS-associated Kaposi's sarcoma among men who have sex with men in a European multicentre study. Int J Cancer. 2007;120:1129-35.

84. Schöfer H, Sachs D. In: Hoffmann C, Rockstroh JK; Kamps BS. HIV Medicine 2007; Flying Publisher 15th Edition; p. 477. Avalilable from $<$ www.HIVMedicine.com>

85. Leão JC, Hinrichsen SL, de Freitas BL, Porter SR. Human herpes virus 8 and Kaposi's sarcoma. Rev Assoc Med Bras.1999;45:55-62.

86. Holmes HK, Stephen LX. Oral lesions of HIV infection in developing countries. Oral Dis. 2002; 8(Suppl. 2):40-3.

87. Jacobson LP, Yamashita TE, Detels R, Margolick JB, Chmiel JS, Kingsley LA, et al. Impact of potent antiretroviral therapy on the incidence of Kaposi's sarcoma and non-Hodgkin's lymphomas among HIV-1-infected individuals. Multicenter AIDS Cohort Study. J Acquir Immune Defic Syndr. 1999;21 Suppl 1:S34-41.

88. Krown SE. Management of Kaposi's sarcoma: the role of interferon and thalidomide. Curr Opin Oncol. 2001;13:347-81.

89. Thomas JO. Acquired immunodeficiency syndrome-associated cancers in Sub-Saharan Africa. Semin Oncol. 2001;28:198-206.

90. Ramírez-Amador V, Esquivel-Pedraza L, Lozada-Nur F, De la RosaGarcía E, Volkow-Fernández P, Súchil-Bernal L, et al. Intralesional vinblastine vs. $3 \%$ sodium tetradecyl sulfate for the treatment of oral Kaposi's sarcoma. A double blind, randomized clinical trial. Oral Oncol. 2002;38:460-7

91. Levine AM, Tulpule A. Clinical aspects and management of AIDSrelated Kaposi's sarcoma. Eur J Cancer. 2001;37: 1288-95.

92. Feller L, Masipa J, Wood N, Raubenheimer E, Lemmer J. The prognostic significance of facial lymphoedema in HIV-seropositive subjects with Kaposi sarcoma. AIDS Res Ther 2008;5:2.

93. Caccialanza M, Marca S, Piccinno R, Eulisse G. Radiotherapy of classic and human immunodeficiency virus-related Kaposi's sarcoma: results in 1482 lesions. J Eur Acad Dermatol Venereol 2008 ;22:297-302.

94. Convissar RA. Laser palliation of oral manifestations of human immunodeficiency virus infection. J Am Dent Assoc. 2002;133:5918; quiz 624-5.

95. Podzamczer D, Miralles P, La Calle Md M, Zarco C, Berenguer J, López Aldeguer J, et al. Recommendations of GESIDA/Spanish National Plan of AIDS on diagnosis and treatment of Kaposi's sarcoma and cervical cancer in HIV-infected patients. Med Clin (Barc). 2002;118:788-95. 
96. Dezube BJ. Management of AIDS-related Kaposi's sarcoma: advances in target discovery and treatment. Expert Rev Anticancer Ther.2002;2:193-200.

97. Coutlée F, Trottier AM, Ghattas G, Leduc R, Toma E, Sanche G, et al. Risk factors for oral human papillomavirus in adults infected and not infected with human immunodeficiency virus. Sex Transm Dis. 1997;24:23-31.

98. Syrjanen S. Human papillomavirus (HPV) in head and neck cancer. J Clin Virol 2005; 32(Suppl 1):S59-66.

99. Kreimer AR, Alberg AJ, Daniel R, Gravitt PE, Viscidi R, Garrett ES, et al. Oral human papillomavirus infection in adults is associated with sexual behavior and HIV serostatus. J Infect Dis. 2004;189:686-98.

100. Arora A, Chiao E, Tyring SK. AIDS malignancies. Cancer Treat Res. 2007; 133:21-67.

101. Cameron JE, Mercante D, O'Brien M, Gaffga AM, Leigh JE, Fidel $\mathrm{PL} \mathrm{Jr}$, et al. The impact of highly active antiretroviral therapy and immunodeficiency on human papillomavirus infection of the oral cavity of human immunodeficiency virus-seropositive adults. Sex Transm Dis. 2005;32:703-9.

102. Robinson PG. The significance and management of periodontal lesions in HIV infection. Oral Dis. 2002;8 Suppl 2:91-7.

103. Teanpaisan R, Douglas CW, Nittayananta W. Isolation and genotyping of black-pigmented anaerobes from periodontal sites of HIV-positive and non-infected subjects in Thailand. J Clin Periodontol. 2001;28:3118.

104. Narani N, Epstein JB. Classifications of oral lesions in HIV infection. J Clin Periodontol. 2001;28:137-45.

105. Ranganathan K, Reddy BV, Kumarasamy N, Solomon S, Viswanathan R, Johnson NW. Oral lesions and conditions associated with human immunodeficiency virus infection in 300 south Indian patients. Oral Dis. 2000;6:152-57.

106. Flaitz C, Wullbrandt B, Sexton J, Bourdon T, Hicks J. Prevalence of orodental findings in HIV-infected Romanian children. Pediatr Dent. 2001;23:44-50.

107. Robinson PG, Boulter A, Birnbaum W, Johnson NW. A controlled study of relative periodontal attachment loss in people with HIV infection J Clin Periodontol. 2000;27:273-6.

108. Chhieng DC, Argosino R, McKenna BJ, Cangiarella JF, Cohen JM. Utility of fine-needle aspiration in the diagnosis of salivary gland lesions in patients infected with human immunodeficiency virus. Diagn Cytopathol. 1999;21:260-4.

109. Mandel L. Ultrasound findings in HIV-positive patients with parotid gland swellings. J Oral Maxillofac Surg. 2001;59:283-6.

110. Mandel L, Kim D, Uy C. Parotid gland swelling in HIV diffuse infiltrative CD8 lymphocytosis syndrome. Oral Surg Oral Med Oral Pathol Oral Radiol Endod. 1998; 85:565-8.

111. Williams FM, Cohen PR, Jumshyd J, Reveille JD. Prevalence of the diffuse infiltrative lymphocytosis syndrome among human immunodeficiency virus type 1- positive outpatients. Arthritis Rheum. 1998;41:863-8.

112. Dave SP, Pernas FG, Roy S. The benign lymphoepithelial cyst and a classification system for lymphocytic parotid gland enlargement in the pediatric HIV population. Laryngoscope. 2007;117:106-13.

113. Navazesh M, Mulligan R, Barrón Y, Redford M, Greenspan D, Alves M, et al. A 4-year longitudinal evaluation of xerostomia and salivary gland hypofunction in the Women's Interagency HIV Study participants. Oral Surg Oral Med Oral Pathol Oral Radiol Endod. 2003;95:693-8.
114. Valentine C, Deenmamode J, Sherwood R. Xerostomia associated with didanosine. Lancet. 1992;340:1542-3.

115. Younai FS, Marcus M, Freed JR, Coulter ID, Cunningham W, DerMartirosian C, et al. Self-reported oral dryness and HIV disease in a national sample of patients receiving medical care. Oral Surg Oral Med Oral Pathol Oral Radiol Endod. 2001; 92:629-36.

116. Mandel L, Surattanont F. Regression of HIV parotid swellings after antiviral therapy: case reports with computed tomographic scan evidence. Oral Surg Oral Med Oral Pathol Oral Radiol Endod. 2002;94:454-9.

117. Beitler JJ, Smith RV, Brook A, Edelman M, Sharma A, Serrano M, et al. Benign parotid hypertrophy on + HIV patients: limited late failures after external radiation. Int J Radiat Oncol Biol Phys. 1999;45:4515 .

118. Turner MD, Ship JA. Dry mouth and its effects on the oral health of elderly people. J Am Dent Assoc 2007 Sep;138 Suppl:15S-20S. Review. Erratum in: J Am Dent Assoc. 2008;139:252-3.

119. Mathews SA, Kurien BT, Scofield RH. Oral manifestations of Sjögren's syndrome. J Dent Res. 2008; 87:308-18.

120. Panayiotakopoulos GD, Aroni K, Kyriaki D, Paikos S, Vouyioukas N, Vlachos A, et al. Paucity of Sjogren-like syndrome in a cohort of HIV1-positive patients in the HAART era. Part II. Rheumatology (Oxford) 2003;42:1164-7.

121. Porter SR, Scully C, Hegarthy AM. An update of the etiology and management of xerostomia. Oral Surg Oral Med Oral Pathol Oral Radiol Endod. 2004;97:28-46.

122. Spina M, Sandri S, Tirelli U. Hodgkin's disease in HIVinfected individuals. Curr Opin Oncol. 1999;11:522-6.

123. Navarro CM, Shibli JA, Ferrari RB, d'Avila S, Sposto MR. Gingival primary extranodal non-Hodgkin's lymphoma as the first manifestation of acquired immunodeficiency syndrome. J Periodontol. 2008;79:5626.

124. Berretta M, Cinelli R, Martellotta F, Spina M, Vaccher E, Tirelli U. Therapeutic approaches to AIDS-related malignancies. Oncogene. 2003;22:6646-59.

125. Spitzer TR, Ambinder RF, Lee JY, Kaplan LD, Wachsman W, Straus DJ, et al. Dose-reduced busulfan, cyclophosphamide, and autologous stem cell transplantation for human immunodeficiency virus-associated lymphoma: AIDS Malignancy Consortium study 020. Biol Blood Marrow Transplant 2008;14:59-66.

126. Miziara ID, Weber R. Oral lesions as predictors of highly active antiretroviral therapy failure in Brazilian HIV-infected children. J Oral Pathol Med. 2008;37:99-106.

127. Greenspan D, Canchola A, MacPhail L, Cheike B, Greenspan J. Effect of highly active antiretroviral therapy on frequency of oral warts. Lancet. 2001; 357:1411-2.

128. Hicks MJ, Flaitz CM, Carter AB, Cron SG, Rossmann SN, Simon CL, et al. Dental caries in HIV-infected children: a longitudinal study. Pediatr Dent. 2000;22:359-64.

129. Eldridge K, Gallagher JE. Dental caries prevalence and dental health behaviour in HIV infected children. Int J Paediatr Dent. 2000;10:1926.

130. Ferris M, Burau K, Schweitzer AM, Mihale S, Murray N, Preda A, et al. The influence of disclosure of HIV diagnosis on time to disease progression in a cohort of Romanian children and teens. AIDS Care. 2007;19:1088-94. 